\title{
evaluation of proximate and mineral contents of termite (Trinervitermes germinatus) from Abakaliki and Ndieze izzi, Ebonyi state, Nigeria
}

\author{
J. N. Afiukwa ${ }^{1}$, C. Okereke ${ }^{2}$ and M. O. Odo ${ }^{3}$ \\ 1,2 Department of Industrial Chemistry, Ebonyi State University, P.M.B. 053, Abakaliki \\ ${ }^{3}$ Department of Food Science and Technology, Ebonyi State University, P.M.B. 053, \\ Abakaliki \\ Correspondence: J. N. Afiukwa, joeafiukwa1960@gmail.com +2348035453180
}

\begin{abstract}
Proximate and mineral content levels of whole Trinervitermes germinatus (Termite), the raw (fresh), fried and wings were evaluated using Standard Methods. Results obtained showed that the wings often removed during processing had the highest iron content $(7.18 \pm 0.012 \mathrm{mg} / \mathrm{Kg})$ with an appreciable calcium level $(925.83 \pm 0.009 \mathrm{mg} / \mathrm{Kg})$ as well as the highest crude fat $(47.50$ $\pm 2.50 \%)$, total carbohydrate $(73.29 \pm 1.44 \%)$ and energy value $\left(763.70 \mathrm{kCal} / 10^{2} \mathrm{~g}\right)$ compared with the commonly eaten fresh and fried parts. The protein contents varied significantly $(p<0.05)$ with the fried sample having the highest value of $41.70 \pm 2.05 \%$ and the wings the least value of $10.76 \pm 1.48 \%$. Total carbohydrates, crude fibre and moisture contents ranged from $32.05-$ $74.23 \%, 10.30-16.50 \%$ and $2.70-17.00 \%$ respectively. The ash content varied in the order; fresh flour $(7.25 \pm 1.25 \%)>$ fried $(4.25 \pm 0.25 \%)>$ wings $(0.65 \pm 0.15 \%)$. Total mineral content distribution decreased in the order; $\mathrm{Ca}>\mathrm{Mg}>\mathrm{Pb}>\mathrm{Fe}>\mathrm{Cu}$ and differed significantly $(\mathrm{p}<0.05)$ between the various parts with the lead level ranging from $1.91-7.53 \mathrm{mg} / \mathrm{Kg}$ ).
\end{abstract}

Keywords: Termite, Proximate, Trace elements, Food Security, Health

\section{INTRODUCTION:}

Inadequacy of food supply and nutritional status are common causes of malnutrition associated with complicated health problems among the rural and urban poor people of Africa and many developing countries of the World. Kent (2002) attributed the wide spread malnutrition prevalent among the rural communities in Africa to inadequate and poor quality food supply. A greater number of people in such areas, due to their poverty level commonly depend on one stable food usually of carbohydrate source. Food insecurity encompasses food directly or indirectly polluted with some traces of toxic mineral elements or those without balanced nutrients such as carbohydrate, protein, fat and essential trace mineral elements. In this sense, the rural and urban poor populace who are in many cases greater in number may be suffering, not only from food inadequacy but food insecurity. Reliefs for these necessary nutrients seem to have been provided by nature-nurtured insects such as Trinervitermes germinatus (Termites), Saturiidae (caterpillars), Rhyncophorus pheonicis (palm weevils), Orycles rhinoceros (palm beetles), Gymnogryllus lucens (crickets), Zonocerus varegatus (grasshopper) and locust (Anacridium melanorhodon) etc. because of their evaluated nutritional and mineral potentials. However, many developing regions of Africa (including Nigeria), Asia, Central and South America consume many of the insects especially termites based on seasonal ubiquity either as dessert, appetizer or as protein supplement in their diet (Ekop, Udoh and Akpan, 2010). For instance, DeFoliart, (1992) stated that "the Yukpa people of Colombia and Venezuela and the Pedi people of South Africa prefer termite foods to fresh meat in some of their traditional diets". $T$. germinatus was recognized as valuable source of animal protein for Zambian's rural poor population because conventional meat from domesticated and wild animals were scarce and beyond the economic level of average poor person in Zambia, (Mwizenge, 1993).

Different studies carried out on these listed edible insects including termites have shown that they contain dependable amounts of the nutrients as well as calcium ( $\mathrm{Ca})$, magnesium $(\mathrm{Mg})$, iron ( $\mathrm{Fe})$, copper (Cu) and zinc (Zn), (Ekop et al, 2010; Osasona and Olaofe, 2010; Nafisa et al, 2008; Onyeike, Ayalogu 
and Okaraonye, 2005; Umoh and Bassir, 1997 and DeFoliart, 1992).

Termite is one of the highly prolific groups in the animal kingdom constituting about $76 \%$ of known surviving animals (Yoloye, 1988). Tokuda (2007) reported that a female termite (queen) lay over 2000 eggs per day and can live up to 45 years. This presents a good incentive for the exploitation of the termite fully organized colony as a supplemental source of food protein, carbohydrate, fat and minerals.

None of the studies carried out on winged termites considered the wings (feather) as a source of nutrient. The nutrient potentials of this specie of insects are underutilized and not fully exploited in many parts of Nigeria and Ebonyi State in particular. Paucity of literature on the nutrient and mineral potentials of the wings which are often isolated and thrown away during processing is the focus of this present study. It is hoped that information revealed by this study shall spur interest and awareness in the consumption of the winged termites whole and entire to derive the maximum utility it offers.

Materials and Method: Sample Collection and Processing: A large quantity of the reproductive winged samples of $T$. germinatus was collected at random at different locations within Ndieze Enyimagu village in Izzi Local Government Area and Abakaliki Urban, Ebonyi State, South East Zone of Nigeria. The harvest was done during the peak of its swarm at night from their termiterum in the Month of April and May, 2012 using entomological net. As a poor flier, the alates are readily blown down in wind speed and attracted to electric or kerosene light so that some samples were handpicked as they fall. Rural dwellers also assisted for maximum harvest. The samples were sorted, washed in deionized water and dried under UV rays of sunlight for 4 hours. The sorted wing sample was also dried under same condition. Two composite samples were obtained based on the Monthly sampling. From each composite, the flesh was divided into two, one part retained as fresh (raw) sample and the second part was further oven fried at $105^{\circ} \mathrm{C}$ for $30 \mathrm{~min}$. to obtain the treatment fried sample. The three samples (fresh, fried and wing) were separately ground with Laboratory mortar and pestle, wrapped in black polyethylene bags, sealed in dry air-tight plastic container and stored in air-tight cupboard prior to Laboratory analysis.

Proximate Analysis: The moisture, crude ash, crude fat, crude fibre and crude protein profile of the fresh, fried and wing samples expressed as a percentage were determined by standard methods described in Onwuka, (2005) and AOAC, (1999).

Moisture content (MC) was determined by heating $10.0 \mathrm{~g}$ of each sample to constant weight in hot aircirculating thermostatic oven at $110{ }^{\circ} \mathrm{C}$, cooling in desiccators and obtaining a constant weight using Mettler P1210 Analytical Balance, Switzerland.

$\% M C=10^{2}[($ wt. of crucible + sample before drying $)$ - (dry wt. of crucible + sample)]/wt. of sample

Ash was determined by charring $3.0 \mathrm{~g}$ of the sample on a hot plate in a fume cupboard and incinerating in a pre-heated muffle furnace, (Bamford, Sheffield England) at $600{ }^{\circ} \mathrm{C}$ for $4 \mathrm{~h}$.

$\%$ Ash $=10^{2}[($ wt. of crucible + Ash $)-$ (wt. of crucible)]/wt. of sample before dry ashing

Fat content was determined by exhaustively extracting $2.0 \mathrm{~g}$ of each sample for $6 \mathrm{~h}$ in a Soxhlet extractor using petroleum ether (AOAC, 1984).

$\%$ Fat $=10^{2} \mathrm{Wt}$. of fat $\mathrm{Wt}$. of sample

Crude fibre was determined by method of Onwuka, (2005). A $2.0 \mathrm{~g}$ of each defatted sample was boiled, refluxed for 30 min with $200 \mathrm{~cm}^{3}$ of a $1.25 \% \mathrm{H}_{2} \mathrm{SO}_{4}$, filtered with watchman GF 45 filter paper and washed with boiling distilled water until the filtrate was neutral. The residue was also boiled for $30 \mathrm{~min}$ with $200 \mathrm{~cm}^{3}$ of carbonate free $1.25 \% \mathrm{NaOH}$ and filtered. The mixture was further filtered, cooled and the residual was dried in an air-tight oven at $100{ }^{\circ} \mathrm{C}$ for $1 \mathrm{~h}$, cooled in a desiccators and weighed $(A)$. The residue was further ashed and re-weighed $(B)$

$\%$ Fibre $=10^{2}(A-B) /$ wt. of sample

Crude protein was estimated by the Kjeldahl method. Total nitrogen, $\mathrm{N}$, in the sample was first determined and $\% \mathrm{~N}$ in the food protein was multiplied with a factor, 6.25 to obtain the \% total protein in the sample. This factor was derived from 100/16 according to Onyeike et al, (2005) and Onwuka, (2005) based on the assumption that the average protein content of most foods is $16 \% \mathrm{~N}$. The sample was digested with conc. $\mathrm{H}_{2} \mathrm{SO}_{4}$ and the digest was distilled with Markham distiller in a fume cupboard to liberate $\mathrm{NH}_{3}$ which was trapped into a $5 \mathrm{~cm}^{3}$ of $2 \%$ $\mathrm{H}_{3} \mathrm{BO}_{3}$. The resulting ammonium borate was titrated against $0.01 \mathrm{MH}_{2} \mathrm{SO}_{4}$.

$\% \mathrm{~N}=10^{2}\left[\left(\mathrm{~V}_{\mathrm{a}}-\mathrm{V}_{\mathrm{b}}\right) \times 0.01 \times 0.01401\right] /$ wt. of sample

Where $V_{a}=$ titre vol. of acid, $V_{b}=$ titre vol. of blank 
Total carbohydrate was estimated by difference; 100 - (\% MC + \% Ash + \% Protein + \% Fibre $)$.

Energy Value: The caloric value $(\mathrm{kcal} / \mathrm{g})$ was calculated by multiplying the mean of crude protein and total carbohydrate by At Water factor of 4 each and that of crude fat multiplied by 9 and summing up the products (Onyeike et al, 1995 and Onyeike and Acharu, 2002).

Total trace metals $(\mathrm{Pb}, \mathrm{Fe}$ and $\mathrm{Cu}$ ) were determined using UV-Vis spectronic 21D LKB, Becton England at $430 \mathrm{~nm}, 510 \mathrm{~nm}$ and $620 \mathrm{~nm}$ wavelengths respectively, while $\mathrm{Ca}, \mathrm{Mg}$ and $\mathrm{Zn}$ were by EDTA titration method.
Data Analysis: Triplicate determinations were carried out on each sample $(\mathrm{N}=3)$ and results are quoted as mean \pm standard error (SE). All reagents used were of analytical grade. The data were assessed by variance analysis (ANOVA) at 0.05 confidence limit using SAS software system, version 9.1, Pearson's correlation and least significant difference (LSD)

Results and Discussion: Table 1 shows the proximate composition and energy profile of the reproductive group of $T$. germinatus and Fig. 1 presents the variations in the nutrient levels.

Table 1: Proximate composition (\%) of T. germinatus

\begin{tabular}{|c|c|c|c|c|c|c|c|}
\hline Sample & Moisture & Ash & Crude Fat & Crude Fibre & Crude Protein & $\mathrm{CHO}$ & $\begin{array}{l}\text { Caloric value } \\
\left(\mathrm{kCal} / 10^{2} \mathrm{~g}\right)\end{array}$ \\
\hline $\begin{array}{l}\text { Fresh } \\
\text { SE }\end{array}$ & $\begin{array}{l}16.50^{\mathrm{a}} \\
\pm 0.50\end{array}$ & $\begin{array}{l}7.25^{\mathrm{a}} \\
\pm 1.25\end{array}$ & $\begin{array}{l}14.70^{\mathrm{C}} \\
\pm 1.20\end{array}$ & $\begin{array}{l}10.45^{\mathrm{C}} \\
\pm 0.15\end{array}$ & $\begin{array}{l}12.13^{b} \\
\pm 0.40\end{array}$ & $\begin{array}{l}53.67^{b} \\
\pm 0.50\end{array}$ & $395.50^{c}$ \\
\hline $\begin{array}{l}\text { Fried } \\
\text { SE }\end{array}$ & $\begin{array}{l}3.90^{b} \\
\pm 0.10\end{array}$ & $\begin{array}{l}4.25^{\mathrm{a}} \\
\pm 0.25\end{array}$ & $\begin{array}{l}26.35^{b} \\
\pm 0.35\end{array}$ & $\begin{array}{l}16.35^{\mathrm{a}} \\
\pm 0.15\end{array}$ & $\begin{array}{l}41.70^{a} \\
\pm 2.05\end{array}$ & $\begin{array}{l}33.80^{\mathrm{C}} \\
\pm 1.75\end{array}$ & $539.15^{b}$ \\
\hline $\begin{array}{l}\text { Wings } \\
\text { SE }\end{array}$ & $\begin{array}{l}2.75^{\mathrm{b}} \\
\pm 0.05\end{array}$ & $\begin{array}{l}0.65^{b} \\
\pm 0.15\end{array}$ & $\begin{array}{l}47.50^{\mathrm{a}} \\
\pm 2.50\end{array}$ & $\begin{array}{l}12.55^{\mathrm{b}} \\
\pm 0.15\end{array}$ & $\begin{array}{l}10.76^{\mathrm{b}} \\
\pm 1.49\end{array}$ & $\begin{array}{l}73.29^{a} \\
\pm 1.44\end{array}$ & $763.70^{a}$ \\
\hline $\begin{array}{l}\text { Mean } \\
\text { SE }\end{array}$ & $\begin{array}{l}7.72 \\
\pm 4.83\end{array}$ & $\begin{array}{l}4.05 \\
\pm 2.17\end{array}$ & $\begin{array}{l}29.52 \\
\pm 10.59\end{array}$ & $\begin{array}{l}13.12 \\
\pm 1.89\end{array}$ & $\begin{array}{l}21.53 \\
\pm 11.12\end{array}$ & $\begin{array}{l}53.59 \\
\pm 12.53\end{array}$ & $1698.35 t$ \\
\hline Range & $2.7-17.0$ & $0.5-8.5$ & $13.5-50.0$ & $10.3-16.5$ & $9.28-43.75$ & $32.05-7$ & 4.23 \\
\hline
\end{tabular}

Means in each column with the same letter superscript are not significant ( $p>0.05)$, those with different letters are significantly different $(p<0.05), S E=$ standard error. $\mathrm{CHO}=$ Carbohydrate

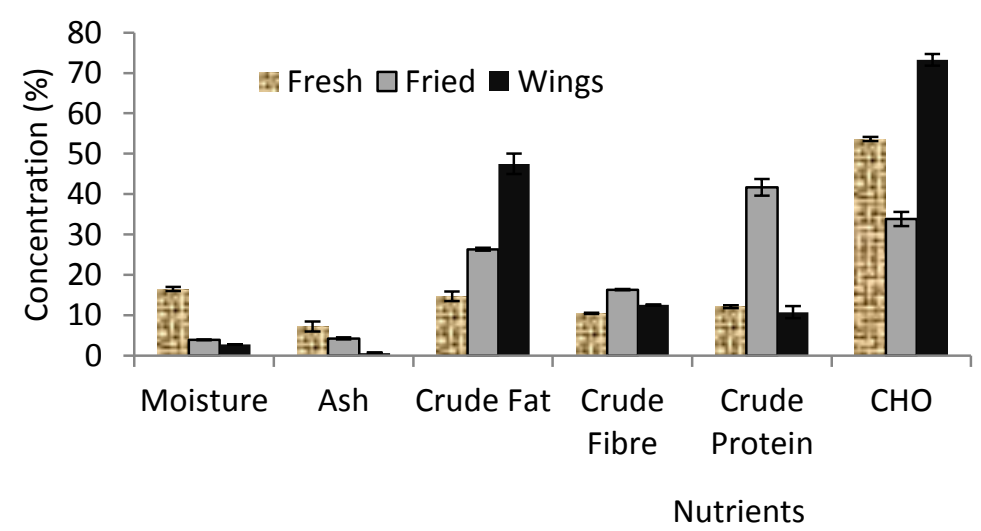

Fig.1: Proximate composition of winged edible Termite 
Carbohydrates (CHO) and Fat: The $\mathrm{CHO}$ and fat contents of the samples varied significantly $(p<0.05)$ with the wings showing the highest $\mathrm{CHO}$ (73.29 \pm $1.44 \%)$ and crude fat $(47.50 \pm 2.5 \%)$ contents compared with the conventionally valued fried or fresh (raw) samples (Fig. 1). The average total $\mathrm{CHO}$ and crude fat obtained $(53.59 \pm 12.53 \%, 29.52+$ $10.59 \%$ respectively) were significantly high ( $\mathrm{p}$ $0.05)$ compared with those of $O$. rhinoceros $(27.7 \pm$ $0.5 \%, 0.55 \pm 0.1 \%)$, R. pheonicis $(35.60 \pm 0.90 \%$, $17.30 \pm 1.24 \%)$, G. lucens (13.08 $\pm 0.001 \%, 26.47 \pm$ $0.001 \%)$ and $Z$. vaiegatus $(24.94 \pm 0.001 \%), 23.63$ $\pm 0.001 \%$ (Onyeike et al, 2005 and Ekop, 2010).

Protein: The protein content of the wing sample $(10.76 \pm 1.49 \%)$ did not differ significantly $(p>0.05)$ with that of the fresh $(12.13 \pm 0.40 \%)$ but is much lower than was obtained in the fried sample $(41.70 \pm$ $2.05 \%$ ). The mean total protein level in the whole samples $(21.53 \pm 11.12 \%)$ was higher by $1.53 \%$ than the result of similar studies on $T$. germinatus (Onyeike et al, 2005) and differed significantly from those of cow milk (3.8\%), hen's egg $(12.4 \%)$ and beef $(18.0 \%)$, (FAO, 1972). The daily protein requirement of $23.56 \%$ (NRC, 1974) can be substantially augmented by incorporating processed termite meat into children, pregnant and lactating mother's diets or even adults who are malnourished.

Crude Ash: The pattern of variation in the ash content followed similar trend in total mineral content of the evaluated parts. The ash content varied in the order, fresh > fried > wing sample (Fig.1), while the total mineral content also varied in the same order. The ash content obtained for the fresh and fried samples were not significant $(p>0.05)$.

Crude Fibre: Crude fibre level differed significantly ( $p$ $<0.05)$ between the parts with the fried sample indicating the value $(16.35 \pm 0.15 \%)$, followed by the wings $(12.55 \pm 0.15 \%)$ and then the fresh $(10.45 \pm$ $0.15 \%)$. The total crude fibre ranged from $10.30-$ $16.50 \%$, an appreciably high value to augment fibre requirements in diets. Fibre in diets is believed to aid weight control, fat reduction and maintain the proper peristaltic movement of the intestinal tract to prevent constipation (Ekop, 2004 and Oduor et al, 2008). The relatively high fibre level observed may be attributed to low chitin content observed in insects generally according to Oduor (2008). Chitin is a complex nitrogen-containing polysaccharide responsible for the hardened exoskeleton of insects.

Moisture content: The variations between the fried and wing samples were not significant $(p<0.05)$, but differed with the fresh sample (Table 1). However, $\mathrm{MC}$ of the whole insect was generally low (7.72 \pm $4.83 \%)$ compared with results of similar studies (Onyeike et al, 2005). The low MC can be of advantage in storage as processed samples may be free from microbial perturbation.

Energy Content: The computed gross energy value of the wing sample $(763.70 \quad \mathrm{kCal} / 100 \mathrm{~g})$ differed significantly $(p<0.05)$ from those of fried (539.15 $\mathrm{kCal} / 100 \mathrm{~g})$ and fresh $(395.50 \mathrm{kCal} / 100 \mathrm{~g})$ samples. The variation observed is evidently due to the remarkable difference in the $\mathrm{CHO}$ and fat contents in the wings. Cumulatively, edible termite may contribute up to $1698.35 \mathrm{kCal} / 100 \mathrm{~g}$ calories in a diet supplemented with it. This may go a long way to augmenting the daily energy requirements of $2500-$ $3000 \mathrm{kCal}$ recommended for adults (Bingham, 1978) although this amount is far greater than was recommended by FAO (1973), (800 - 1200kCal). No one insect or food source consumed independently as diet can meet the RDA value of $2500-3000 \mathrm{kCal}$. It is therefore reasonable and economical to supplement diets with edible termite or be eaten as dessert, delicacy or appetizer to meet up with the energy demand of the body.

Pearson's correlation matrix of the proximate compositions (Table 2) indicated a high negative relationship between ash/fat, fat/moisture, moisture/fibre and protein/ $\mathrm{CHO}$ levels. Thus increasing trend observed in crude fat content suggests a decreasing trend in the values of crude ash content of the samples. Similarly, high positive correlation was observed for crude ash/moisture, crude fibre/protein and crude fat/ $\mathrm{CHO}$ implying that both ash and moisture contents, for example, were increasing or decreasing correspondingly. 
Am. J. Food. Nutr, 2013, 3(3): 98-104

Table 2: Pearson's Correlation Matrix of the Nutrient Profile of T. germinatus

\begin{tabular}{lllllll}
\hline & Ash & Fat & Moisture & Fibre & Protein & CHO \\
Ash & 1.0000 & & & & \\
Fat & $-0.9409^{\mathrm{a}}$ & 1.0000 & & & & \\
& $0.0051^{\mathrm{b}}$ & & & & & \\
Moisture & $0.8325^{\mathrm{a}}$ & -0.8128 & 1.0000 & & & \\
& $0.0398^{\mathrm{b}}$ & 0.0493 & & & & \\
Fibre & $-0.2804^{\mathrm{a}}$ & 0.1962 & -0.7218 & 1.0000 & & \\
& $0.5905^{\mathrm{b}}$ & 0.7094 & 0.1053 & & & \\
Protein & $0.0810^{\mathrm{a}}$ & -0.2091 & -0.3940 & 0.9097 & 1.0000 & \\
& $0.8787^{\mathrm{b}}$ & 0.6909 & 0.4395 & 0.0119 & & \\
Carbohydrate & $-0.5233^{\mathrm{a}}$ & 0.6319 & -0.0708 & -0.6315 & -0.8868 & 1.0000 \\
& $0.2867^{\mathrm{b}}$ & 0.1783 & 0.8940 & 0.1787 & 0.0185 & \\
\hline
\end{tabular}

Upper values 'a' represent correlation; Lower values 'b' denote level of significance on each row

Trace metal concentration: Variations in the mineral profile of $T$. germinatus are presented in Table 3, while Table 4 shows the Pearson's correlation analysis of the minerals. It can be observed that the wing sample had the highest level of iron $(7.18 \pm$ $0.012 \mathrm{mg} / \mathrm{kg}$ ), Fig.2b, with appreciable amount of calcium $(925.83 \pm 0.009 \mathrm{mg} / \mathrm{kg})$ more than was obtained for the fresh sample (801.62 \pm 0.012 $\mathrm{mg} / \mathrm{kg}$ ), Fig. 2a. The fresh sample showed the highest level of magnesium (1009. $26 \pm 0.014$ $\mathrm{mg} / \mathrm{kg})$ and lead $(7.50 \pm 0.014 \mathrm{mg} / \mathrm{kg})$, while fried sample indicated the highest calcium content $(957.94 \pm 0.017 \mathrm{mg} / \mathrm{kg}$ ). Values of $\mathrm{Ca}$ and $\mathrm{Mg}$ (Fig. 2a) were significantly high ranging from 801.62 $957.97 \mathrm{mg} / \mathrm{kg}$ and 367.38 - $1009.30 \mathrm{mg} / \mathrm{kg}$ respectively and were much higher than those of similar studies in hen's egg $(450 \mathrm{mg} / \mathrm{kg} \mathrm{Ca})$ and beef (130 mg/kg Ca) (FAO, 1972). Iron, lead and copper ranged from $1.22-7.20 \mathrm{mg} / \mathrm{kg}, 1.91-7.53$ $\mathrm{mg} / \mathrm{kg}$ and $0.0957-0.1357 \mathrm{mg} / \mathrm{kg}$ respectively. The cumulative total mineral distribution in the edible termite (Table 3) decreased in the order $\mathrm{Ca}$ $>\mathrm{Mg}>\mathrm{Pb}>\mathrm{Fe}>\mathrm{Cu}$. These mineral elements except $\mathrm{Pb}$ are very essential for the growth and development of animals and plant and not a health risk at their trace threshold. Calcium and iron are recommended as nutrients to abate lead absorption and toxicity in humans (Barton, 1978). Zinc was not detected probably owing to the titration method used.

Table 3: Trace Mineral concentrations $(\mathrm{mg} / \mathrm{kg})$ in $\mathrm{T}$. germinates

\begin{tabular}{|c|c|c|c|c|c|c|}
\hline $\begin{array}{l}\text { Fresh } \\
\text { SE }\end{array}$ & $\begin{array}{l}\mathrm{Ca} \\
801.62^{\mathrm{c}} \\
\pm 0.012\end{array}$ & $\begin{array}{l}\mathrm{Mg} \\
1009.26^{\mathrm{a}} \\
\pm 0.014\end{array}$ & $\begin{array}{l}\mathrm{Fe} \\
1.24^{\mathrm{c}} \\
\pm 0.009\end{array}$ & $\begin{array}{l}\text { Cu } \\
0.110^{a} \\
\pm 0.006\end{array}$ & $\begin{array}{l}\mathrm{Pb} \\
7.50^{\mathrm{a}} \\
\pm 0.014\end{array}$ & $\begin{array}{l}\mathrm{Zn} \\
\mathrm{nd}\end{array}$ \\
\hline $\begin{array}{l}\text { Fried } \\
\text { SE }\end{array}$ & $\begin{array}{l}957.94^{a} \\
\pm 0.017\end{array}$ & $\begin{array}{l}948.75^{b} \\
\pm 0.017\end{array}$ & $\begin{array}{l}2.01^{\mathrm{b}} \\
\pm 0.014\end{array}$ & $\begin{array}{l}0.137^{a} \\
\pm 0.006\end{array}$ & $\begin{array}{l}5.44^{b} \\
\pm 0.009\end{array}$ & nd \\
\hline $\begin{array}{l}\text { Wings } \\
\text { SE }\end{array}$ & $\begin{array}{l}925.83^{b} \\
\pm 0.009\end{array}$ & $\begin{array}{l}367.40^{c} \\
\pm 0.012\end{array}$ & $\begin{array}{l}7.18^{a} \\
\pm 0.012\end{array}$ & $\begin{array}{l}0.12^{a} \\
\pm 0.003\end{array}$ & $\begin{array}{l}1.92^{c} \\
\pm 0.006\end{array}$ & nd \\
\hline $\begin{array}{l}\text { Mean } \\
\text { SE }\end{array}$ & $\begin{array}{l}895.13 \\
\pm 41.28\end{array}$ & $\begin{array}{l}775.13 \\
\pm 17.70\end{array}$ & $\begin{array}{l}3.47 \\
\pm 1.62\end{array}$ & $\begin{array}{l}0.12 \\
\pm 0.01\end{array}$ & $\begin{array}{l}4.95 \\
\pm 1.41\end{array}$ & nd \\
\hline Range & $\begin{array}{l}801.62- \\
957.97\end{array}$ & $\begin{array}{l}367.38- \\
1009.30\end{array}$ & $\begin{array}{l}1.22- \\
7.20\end{array}$ & $\begin{array}{l}0.0957- \\
0.1357\end{array}$ & $\begin{array}{l}1.905- \\
7.53\end{array}$ & - \\
\hline RDA & $\begin{array}{l}210-800 \\
1000-1300\end{array}$ & $\begin{array}{l}30-130 \\
240-400\end{array}$ & $\begin{array}{l}0.27-30 \\
08-27\end{array}$ & $\begin{array}{l}200-440 \\
700-1000\end{array}$ & $\begin{array}{l}\text { nil } \\
\text { nil }\end{array}$ & $\begin{array}{l}2-5 \text { children } \\
8-12 \text { adult }\end{array}$ \\
\hline
\end{tabular}


Am. J. Food. Nutr, 2013, 3(3): 98-104

Table 4: Pearson's Correlation Matrix of the mineral Profile of $T$. germinates

\begin{tabular}{lllllll}
\hline $\mathrm{Zn}$ & $\mathrm{Zn}$ & $\mathrm{Fe}$ & $\mathrm{Pb}$ & $\mathrm{Mg}$ & $\mathrm{Ca}$ & $\mathrm{Cu}$ \\
$\mathrm{Fe}$ & - & & & & \\
$\mathrm{Pb}$ & - & 1.000 & & & & \\
$\mathrm{Mg}$ & - & -0.968 & 1.000 & & & \\
$\mathrm{Ca}$ & - & -0.0001 & & & & \\
$\mathrm{Cu}$ & - & -0.999 & 0.959 & 1.000 & & \\
& & 0.0001 & $<0.0001$ & & & \\
$\mathrm{C}$ & 0.432 & -0.645 & -0.402 & 1.000 & 1.000 \\
\hline
\end{tabular}

Upper values 'a' represent correlation; Lower values 'b' denote level of significance on each row

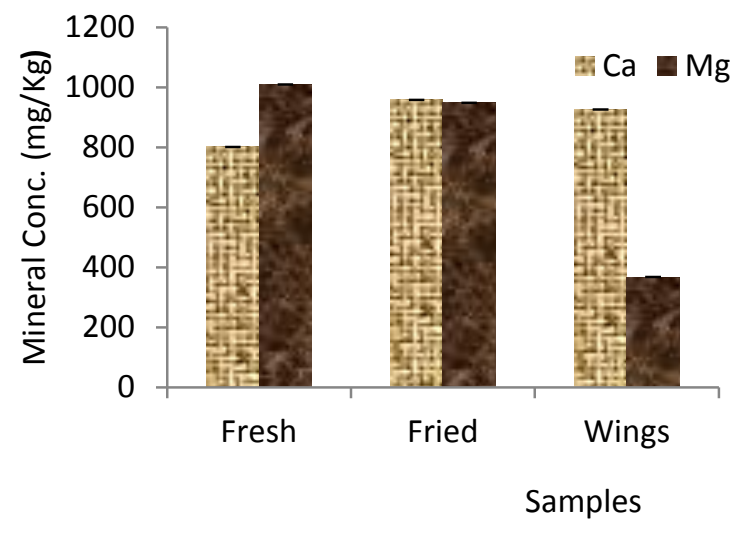

Fig.2a: Concn. of $\mathrm{Ca}$ and $\mathrm{Mg}$ in winged edible Termite

Part of the premium attached to consumption of the insect besides its high nutritional value, was the reduction of serum cholesterol, agent of tissue repairs and hastening the healing of wounds and burns (Goodman, 1989). This function is attributed to the chitin component of the insect. Excess cholesterol $\left(\mathrm{C}_{27} \mathrm{H}_{45} \mathrm{O}_{11}\right)$ may lead to coronary thrombosis (heart attack). However, the high level of $\mathrm{Pb}$ observed in this study is worrisome. Lead is highest in the fresh meat $(7.50+0.014 \mathrm{mg} / \mathrm{kg})$ followed by the fried sample $(5.44 \pm 0.009 \mathrm{mg} / \mathrm{kg})$. Lead is a known cumulative poison not recommended at any threshold level because of its devastating health related issues. The risk factors include high blood pressure, infertility, brain derailment, abortion, miscarriage, autism in children, cardiovascular diseases, kidney and central nervous system damage among others (Ming-HO, 2001, and

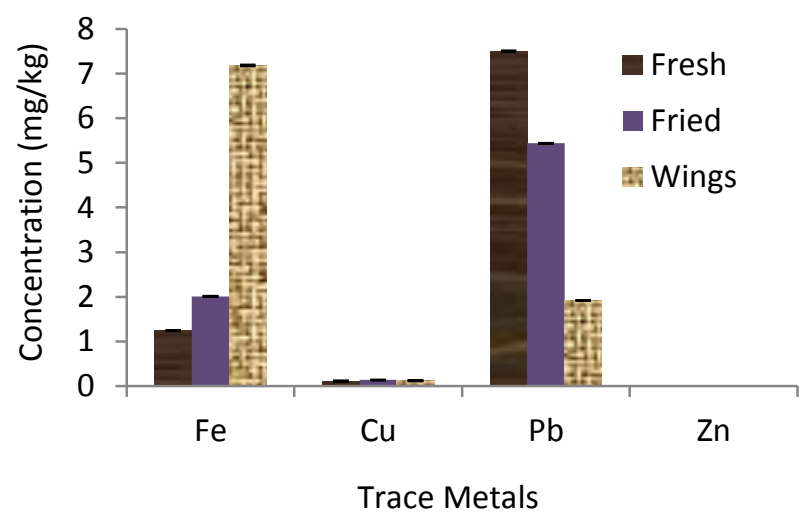

Fig.2b: Concn. of trace minerals $(\mathrm{mg} / \mathrm{Kg})$ in winged edible Termite

NIOSH, 2007 In: Afiukwa and Egu, 2011). The result of the lead concentration may not be general to termites from elsewhere but peculiar to most parts of Ebonyi State especially, Abakaliki and the Enyigba Areas well known for their rich $\mathrm{Pb}-\mathrm{Zn}$ deposits. Lead is ubiquitous and pollutes the soil, water and air to a high degree (Afiukwa, 2011 and Oti et al, 2012).

Conclusion: This study has revealed the great nutrient and energy potentials of the commonly disregarded edible termite wings. It has high $\mathrm{Ca}, \mathrm{Fe}$, $\mathrm{CHO}$ and fat contents with significant quantum of energy that is comparable with the mineral and nutrient levels of the often preferred fresh and fried termite meals. As a whole, the T. germinatus is rich in nutrients, $\mathrm{Ca}, \mathrm{Mg}$ and $\mathrm{Fe}$ minerals, but the high $\mathrm{Pb}$ level observed in this case places one at the risk of consuming species obtained from the lead endemic areas of Ebonyi State. 
Recommendations: Since termites are common detritivores, living on wood and other plant matter for food and inhabit in self-made soil termiteria, there may be need to culture the insect and investigate the chemistry of its hydrogen generation from biomass for bio-energy generation.

Acknowledgement: The researchers acknowledge with thanks the Department of Food Science and Technology, Ebonyi State University for permitting the use of their Laboratory, equipment and space.

\section{REFERENCES}

Afiukwa, J. N. (2011), Evaluation of heavy metals and pollution indices in some water samples in Ebonyi State, Nigeria. J. Poll. Res. India 30(4): $443-447$

Afiukwa, J. N. and Egu, C. M. (2011), Survey of environmental lead and manganese in water supply in selected Areas of Ebonyi State, Nigeria. Chemical Society of Nigeria (CSN) Conf. Proceedings, Ilorin, pp. EN 129 - 133

AOAC, (1999), Official Method of Analysis, $15^{\text {th }}$ edn. (Gaithersburg, S edition). Association of Analytical Chemists Press, Washington DC, USA. pp. 78-90

Barton, J. (1978), Effect of Calcium on the absorption and retention of Lead. J. Lab. Clinical Med. 91: 366

Bingham, S. (1978), Nutrition: A Consumer Guide to good eating. TransWorld, London. pp. 123-127

Defoliart, G.R. (1992), Insects as human food. J. Crop Protection 11: 395-399

Ekop, A.S. (2004), Effects of processing on the chemical composition of maize. Conf. proceedings of Nigerian Society of Biochemistry and Molecular Biology, UNICAL.

FAO, (1972), Amino acid content of food and biological data on proteins. Report of Food and Agricultural Organization/United National Joint Committee, Rome. P. 116

Food and Agricultural Organization, FAO, (1973), Energy and Protein requirements, WHO, Geneva, Switzerland

Goodman,W.G. (1989), Chitin: A magic bullet. Food Insect News letter 3: 6-9

Kent, G. (2002), Africa's Food Security under Globalization. AJFANS 2: 22-29

Ming-HO, (2007), Environmental Toxicology, impacts of environmental toxicants on living systems. Lewis Publishers, London. pp. 151-199

Mwizerige, S. T. (1993), Delicious Insects: Seasonal delicacies in the diet of Rural Zambians. The World and I. Lusaka 8: 234

Nafisa, M. EH; Sara, Y. H; Amr, B. H; Mohamed, M. E and Elfadil, E. B.(2008), Nutritional evaluation and
Physicochemical properties of boiled and fried Tree Locust. Pakistan J. Nutrition 7 (2): 325-329

$\mathrm{NIOSH}$, (2007), U.S. National Institute for Occupational Safety and Health. Adult bloods lead epidemiology and surveillance.

http:/www.cdc.gov/niosh/topics/ABLEsables.descriptio. $\mathrm{htm} /$

Oduor, P. M.; Struszezuk, M. H. and Peter, M. G. (2008), Characterization of Chitosan from Blowfly Larvae and some Crustacean species from Kenyan Marine Waters prepared under different conditions. Discovery and Innovation. 20 (2): 129-142

Onwuka, G.I. (2005), Food Analysis and Instrumentation Theory and Practice. $1^{\mathrm{St}}$ edn. HG Support Press, Lagos, Nigeria. pp. 64-92

Onyeike, E. N. and Acheru, G. N. (2002), Chemical composition of selected Nigerian oil seeds and physicochemical properties of the oil extracts. Food Chem. 77: 431-437

Onyeike, E. N; Ayalogu, E. O. and Okaraonye, C. C. (2005), Nutritive value of the larva of raphia palm beetle (Orycles rhinoceros) and weevil (Rhynohorus phenoicis) J. Food and Agriculture, 85: 1822-1828.

Onyeike, E. N; Olungwe, T and Uwakwe, A.A. (1995), Effect of heat treatment and defatting on the proximate composition of some Nigerian local soup thickeners. $J$. Food Chem. 53: 173 - 175

Osasona, A. I. and Olaofe, O. (2010), Nutritional and functional properties ofCirina forda larva from Ado Ekiti, Nigeria. African J. Food Sci. 4 (12): 775-777

Oti, W. J.O; Nwabue, F. I. and Afiukwa, J. N. (2012), Analysis of heavy metals in soil of Enyigba and Abakaliki using Proton Induced X-Ray Emission (PIXE) Spectroscopy. On-line J. Environment and Pollution 1 (2): 1927-0917

retrieved 2007/10/04

Tokuda, G. and Watanabe, H. (2007), Hidden celluases in termites; Revision of old hypothesis. Biology letters 3(3): 336-339

Umoh, and Bassir, (1977), Lesser known sources of protein in some Nigerian peasant diets. Food Chem. 2: 315321

Wikipedia Inc. (2012), Recommended intake of vitamins and essential minerals, www.crnusa.org/benpdfs. Retrieved 2012/10/21

Wikipedia Inc. (2012). Termite (order: isoptera) http:/www.animalpicturesarchive.com Retrieved 2012/09/08

Yologe, V. L. (1988), Basic Invertebrate Zoology. $1^{\text {st }}$ edn. Univ. of llorin Press, p.192 